\title{
A closer eye on appraisals
}

\author{
By John R. Payne \\ Assistant to the Director \\ University of Texas at Austin
}

\section{The new tax law and its effect on gifts, donors, and} appraisers.

$\mathbf{T}$ he Tax Reform Act of 1984, which became effective on January 1,1985 , will have a dramatic impact on gift acquisitions by librarians. These are some of the features of the new legislation:

- Appraisals for gifts valued over $\$ 5,000$ are mandatory.

- Libraries are required to provide a formal accounting to the IRS and to past donors about the disposition of gifts held less than two years.

- New penalties are levied to donors and appraisers for the over-evaluation of gifts.

- Appraisers who have performed work unacceptable to the IRS in the past are prevented from submitting subsequent appraisals for income tax purposes.

These new and tougher laws reflect a more critical approach by the IRS for regulating the appraisal of donated property. The main points of the Act can be summarized as follows: ${ }^{1}$

1. A "qualified appraisal" is required for all contributions valued at $\$ 5,000$ or more and must be filed with the tax return. Essentially this legislates the need for appraisals on a much broader scale than before. A "qualified appraisal" must include the following:

a) a description of the property appraised;

I“'The Tax Reform Act of 1984," Conference Report on the Deficit Reduction Act of 1984: Federal Taxes, Bulletin 29 Extra, June 29, 1984. Explanation of the Tax Reform Act of 1984 (Chicago: Commerce Clearing House, 1984). b) the fair market value of the property on the date of contribution and the specific basis for the valuation;

c) a statement that the appraisal was prepared for income tax purposes;

d) the qualifications of the appraiser;

e) the signature and taxpayer identification number (TIN) of the appraiser.

2. While the Act does not say what a "qualified appraiser" is, it does say that he may not be:

a) the taxpayer making the donation;

b) the donee;

c) any person employed by, related to, or in close association with the donor;

d) a party to the transaction in which the taxpayer acquired the property.

This is perhaps the most questionable aspect of the new law, for it precludes from the appraisal activity those booksellers who have been instrumental in the formation of collections and who would be eminently qualified to judge their fair market value.

3. A new provision concerning the disposition of donated property is of greatest concern to librarians. If property is sold, exchanged, or otherwise disposed of by the receiving institution within two years after its receipt, the institution must make a statement for the IRS and the original donor giving:

a) the name, address, and TIN of the donor;

b) a description of the property;

c) the date of the contribution;

d) the amount received on the disposition; 
e) the date of such disposition.

Institutions are subject to penalties ranging from $\$ 50$ to $\$ 50,000$ per year for failure to comply.

Essentially this provides a second opportunity for the IRS to verify the accuracy of the original appraisal. For if a gift to a library valued at $\$ 5,000$ is sold or traded by the library within two years for less than that amount, the IRS may feel it has reason to question the accuracy of the initial appraisal.

4. Appraisals will not be accepted if the fee is based on a percentage of the appraised value of the property.

5. Other items discuss:

a) additional taxes to be levied to the taxpayer resulting from underpayment of taxes based on inaccurate appraisals;

b) the refusal by the IRS to accept appraisals by persons who have prepared inaccurate appraisals in the past;

c) the civil penalty of $\$ 1,000$ that can be imposed against an appraiser for aiding and abetting an understatement of tax liability by providing inaccurate appraisals.

\section{Art appraisals}

The primary area of abuse of evaluations has traditionally been with the fine arts. Karen Carolan, senior appraiser with the IRS National Office, indicates the problem became apparent 20 years ago: "In the 1960s art over-valuations were so serious that the art world realized that Congress might limit the tax deductions for charitable donations. With less incentive for people to give art objects away, fewer objects would be bought and donated. As a result, the IRS got together with art dealers and museum officials to develop a system to monitor values. The Commissioner's Art Advisory Panel, established in 1968, was the result." ${ }^{2}$ In November 1980 the Art Print Advisory Panel was authorized to deal with abusive tax shelters in the area of multiple art works (prints). The latest development, in June 1984, was the expansion of the original Art Advisory Panel from its original 12 members to 22 in order to deal with primitive and oriental art. These two panels are supported by the Art Valuation Group in the National Office of the IRS.

Panel members include art and print dealers, museum directors, curators, publishers, and scholars. They meet twice a year in Washington, serve two to three year terms, and are not paid for their services.

The purpose of the panels is to make recommendations to the IRS regarding the acceptability of taxpayer appraisals based on an examination and discussion of all relevant documents. After the

${ }^{2}$ Karen Carolan, "Documenting Art Appraisals for Federal Income Tax Purposes-Estates, Gifts and Income Tax; Art Tax Shelter Problems." In Representing Artists, Collectors, and Dealers 1983 (New York: Practicing Law Institute, 1983), p.472. panel meetings, the National Office art appraisers prepare valuation reports on the rejected appraisals and taxpayers are notified of their findings through the District Office.

All appraisals of art with a claimed value of $\$ 20,000$ or more are automatically referred to the appropriate panel. Appraisal values normally are in the five to six figure range. In 1982 (the latest

\section{More stringent rules govern donors' activities.}

available figures) the Art Advisory Panel reviewed 727 items with an aggregate taxpayer valuation of $\$ 84$ million. The panelists recommended adjustments of approximately $\$ 15$ million, amounting to an $11 \%$ reduction of charitable contribution claims and $28 \%$ increase of estate and gift appraisals. From 1980 to 1983 the Art Print Panel evaluated approximately 1,030 print images with an aggregate taxpayer valuation of approximately $\$ 176$ million. The panel recommended reductions of $\$ 174$ million or $99 \%$ of the total recommended value. $^{3}$

The Art Advisory Panels are now, however, under investigation by the House Government Activities Subcommittee for their nearly exclusive dependence on appraisers drawn from the Art Dealers Association of America (ADAA). Formed in 1962, the ADAA has been doing appraisals since its inception, and while some have been questioned by the IRS, few if any have been challenged successfully. The Subcommittee is concerned about the possible conflict of interest when IRS panel members (i.e., ADAA members) are evaluating appraisals rendered by other ADAA members. It has been reported that suggestions for reform will be forthcoming in the Subcommittee's report. ${ }^{4}$

It is important to note that the IRS has no plans for an advisory panel for books and archives because abuse in the evaluation of these kinds of materials is not sufficient to warrant such a panel.

\section{Appraisals and IRS regulations}

The basis of the IRS regulations is Revenue Procedure $66-49^{5}$ from the Internal Revenue Code of 1954, where "Fair Market Value" is defined as "the

${ }^{3}$ Carolan, ibid., p.476.

4"When Appraisers Collide," Art \& Auction, July/August 1984 .

${ }^{5}$ Internal Revenue Service Guidelines for Appraisals of Donated Properties; Revenue Procedure 66-49 in Internal Revenue Bulletin (July-December 1966), pp. 1257-59. 
price at which property will change hands between a willing buyer and a willing seller, neither being under any compulsion to buy or sell and both having reasonable knowledge of relevant facts."

Sales of comparable property. The use of "comparables" is recognized by the IRS as an acceptable approach to determining fair market value. This is the process of drawing valid correlations between

\section{Evaluation of gifts to}

\section{libraries should be based on}

\section{Fair Market Value.}

property to be appraised and similar or "comparable" property that has recently been sold. The weight given to each sale must take several things into consideration:

1) the degree of similarity between the property sold and the appraisal property;

2) the time of the sale (that is, how close it is to the valuation date);

3 ) the circumstances of the sale;

4) the condition of the market in which the sale took place.

Opinions of experts. Opinion evidence is also accepted by the IRS as a means of determining fair market value. The weight given to opinion evidence, however, depends on its origin and the thoroughness with which it is supported by experience and facts. The underlying facts must support the opinion; otherwise such expert opinion will be discounted.

Appraisal format. Revenue Procedure 66-49 requires the following to be part of each appraisal report:

1) a statement of value and the appraiser's definition of that value, i.e. Fair Market Value;

2) the basis upon which the appraisal was made, including any restrictions, understandings, or covenants limiting the use or disposition of the property;

3) a complete description of the item;

4) a statement of the factors upon which the appraisal was based, including the use of comparables such as prices quoted in book dealers's catalogues and recent auction results;

5) a summary of the appraiser's qualifications;

6 ) the dates on which the property was examined and on which the appraisal was made;

7) the signature of the appraiser.

\section{IRS review of valuation appraisals}

While the IRS is responsible for reviewing ap- praisals, it is not responsible for making them, and the burden of supporting fair market value rests with the taxpayer (and his appraiser). The IRS does not give recognition to any appraiser or organization of appraisers and does not accept appraisals without question. Thus while an appraiser's memberships in professional associations will be points in his favor, they do not remove him from question. Furthermore, the IRS does not approve valuations or appraisers before the actual filing of a tax return, nor does it issue advance rulings approving or disapproving appraisals. In other words, there are no trial runs.

The resolution of questions about valuations of charitable contributions is the responsibility of the IRS Appeals Officer. His or her purpose is to resolve controversies without litigation in a manner fair to the government and the taxpayer. In reviewing an income tax return the IRS may accept the claimed value of the donated property or make its own determination of fair market value. In either case the IRS has the following options:

1) to contact the taxpayer for more information;

2) to refer the valuation problem to an IRS appraiser or valuation specialists;

3) to contract with an independent appraiser to reappraise the property;

4) to refer works of art to the appropriate advisory panel.

\section{Professional appraisal associations}

After the IRS the most important organizations offering guidelines for appraisers are these three appraisal associations:

- American Society of Appraisers, Paul L. O' Brien, Executive Director, P.O. Box 17265, Washington, DC 20041; (703) 620-3838.

- Appraisers Association of America, Victor Wiener, Executive Director, 60 East 42nd Street, New York, NY 10165; (212) 867-9775.

-International Society of Appraisers (An Association of Personal Property Appraisers), Maurice E. Fry, President, P.O. Box 726, Hoffman Estates, IL 60195; (312) 882-0706.

Membership in these associations requires:

1) specialized knowledge of one or more kinds of property;

2) submission of representative appraisal reports; lent;

3) five years of full time experience or its equiva-

4) a written examination (ASA only);

5) adherence to the societies's code of ethics and professional conduct. ${ }^{6}$

While the IRS provides guidelines for the content of appraisal reports, the appraisal associations's code of ethics concerns additionally the ap-

\footnotetext{
${ }^{6}$ American Society of Appraisers, The Principles of Appraisal Practice and Code of Ethics (Washington: The Society, 1968). Last reprinted August 1983.
} 
praiser's duties and responsibilities to his client, to other appraisers, and to the public at large. The following is a composite of guidelines by the three associations.

\section{Appraiser's duties and responsibilities}

1. While there are several kinds of value-retail, forced sale, replacement value for insurance purposes, etc. - it is the appraiser's responsibility to ascertain which is pertinent to the particular undertaking and to explain and describe what is meant by the particular value chosen. The evaluation of gifts to libraries should be based on Fair Market Value.

2. The relationship between client and appraiser is not one of principal and agent. The appraiser's primary obligation to his client is to reach complete and accurate conclusions and numerical results regardless of the client's wishes. Thus if the client wants a book valued at $\$ 1,000$ while its real value is $\$ 500$, the appraiser must stand by his judgment. The appraiser is the expert.

3 . The employment to conduct an appraisal is a confidential matter between the appraiser and his client and must not be discussed without the client's consent. While the knowledge that a very fine library is being appraised would be of considerable interest to the book world, that information is not for the appraiser to share. Similarly, the appraised value of a property and the contents of an appraisal report are private matters.

4. It is good practice for the appraiser to prepare a written contract covering objectives, scope of work, time of delivery of report, fees, etc.

5. Collaboration between appraisers is desirable in some situations, such as to expedite the completion of work or to obtain the benefit of a combined judgment. In such cases all collaborators should sign a joint report.

\section{Unethical appraisal practices}

1. It is unethical for an appraiser to contract for work for a fixed percentage of the amount of value. The Tax Reform Act of 1984 emphasizes this.

2. In some cases where two or more appraisers have been engaged by a single client to make independent appraisals of the same property, the client has the right to expect opinions that have been reached independently. It is thus unethical for appraisers to collaborate or consult with one another or make use of each other's findings.

Many other duties, responsibilities, and unethical practices are outlined in various publications by the appraisal associations. The fullest is presented by the International Society of Appraisers.

\section{The Association of College and Research Libraries}

A position on the appraisal of gifts was developed by ACRL in 1960 and revised in 1973. It can

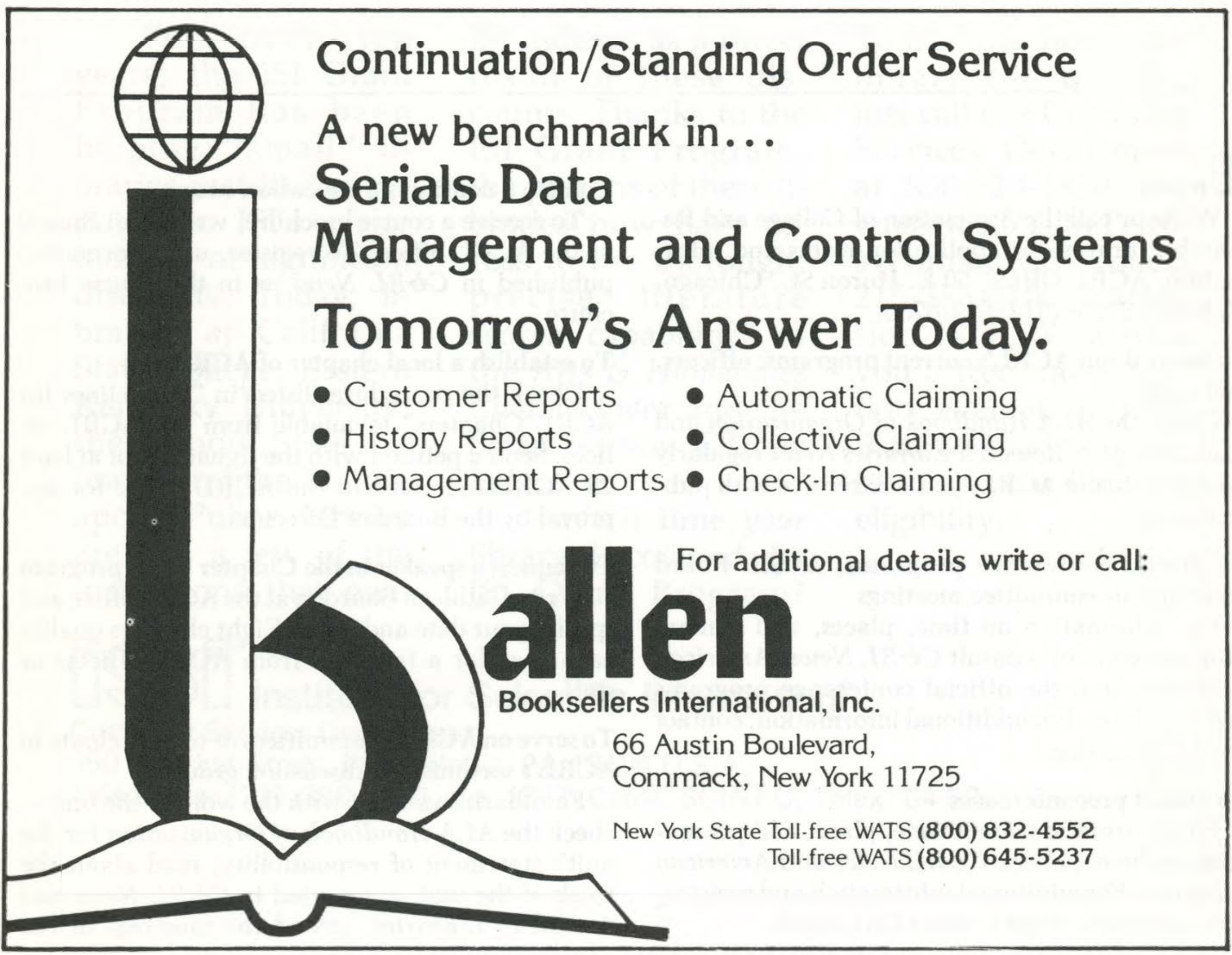


be summarized by saying that the library is recognized as an interested party when receiving donations and should be removed from the actual appraisal process other than to facilitate that process by directing donors to price guides, giving references to qualified appraisers, and helping with clerical work such as preparing a list of the donation. The question about who should pay for appraisals - the donor or the library - falls in ACRL's judgment to the donor. ${ }^{7}$

7"Statement on Appraisal of Gifts," C\&RL News, March 1973, p.49. Reprinted in ACRL's

\section{Summary}

The Tax Reform Act of 1984 serves notice to donors and receiving institutions that closer attention will be given to valuations of donations. Supplementing the new tax law is a host of regulations by the IRS and other agencies that establish an acceptable framework for gift appraisals. The primary effect of the new law is to encourage responsible behavior of donors and appraisers, while librarians must take on new procedures for the control and documentation of their collections.

Guidelines on Manuscripts and Archives (1977).

\section{How to participate in ACRL}

\section{Information for new members and potential members.}

\section{$\mathbf{T}$}

Write or call the Association of College and Research Libraries for application forms and information: ACRL Office, 50 E. Huron St., Chicago, IL 60611-2795; (312) 944-6780.

To learn about ACRL's current programs, officers, and units

Check the ALA Handbook of Organization and read College \& Research Libraries News regularly (as a member of ACRL, you will receive both publications).

To attend conference programs, ACRL Board meetings, or committee meetings

For information on time, places, and general program content, consult $C \& R L$ News, American Libraries, and the official conference programs and schedules. For additional information, contact the ACRL office.

\section{To attend preconferences}

For information about time, place, and preconference theme, check $C \mho R L$ News and American Libraries. For additional information and registration materials, write to the ACRL office.
To take a continuing education course

To receive a course brochure, write Gail Russell at the ACRL office. To register, use information published in C\&RL News or in the course brochure.

To establish a local chapter of ACRL

Check the procedures listed in "Guidelines for ACRL Chapters" (available from the ACRL office). Send a petition with the signatures of at least 25 ACRL members to the ACRL office for approval by the Board of Directors.

To request a speaker in the Chapter Visits program

Write Cathleen Bourdon at the ACRL office and specify your date and topic. Eight chapters qualify each year for a free visit from ACRL officers or staff.

To serve on ACRL's committees or to participate in ACRL's sections and discussion groups

Familiarize yourself with the work of the unitcheck the ALA Handbook of Organization for the unit's statement of responsibility, read about the work of the unit as reported in C $b R L N e w s$ and American Libraries, attend the meetings of the 